UDC 811.411.21+ 811.161.2

DOI https://doi.org/10.24919/2308-4863/41-2-19

\author{
Mariia LYKHOSHERSTOVA, \\ orcid.org/0000-0003-4026-0539 \\ Candidate of Philological Sciences, \\ Associate Professor at the Department of Eastern Philology \\ Kyiv National Linguistic University \\ (Kyiv,Ukraine) mariia.lykhosherstova@knlu.edu.ua
}

Daryna BURIAK,

orcid.org/0000-0002-5211-0688

Master's student of the Faculty of Oriental Studies

Kyiv National Linguistic University

(Kyiv,Ukraine)venetika99@gmail.com

\title{
HYPOTHESIS OF LINGUISTIC RELATIVITY IN ARABIC AND UKRAINIAN IN THE CONTEXT OF TRANSLATION PROBLEMS
}

The article presents the issue of the untranslatability of nationally colored vocabulary and cultural contexts on the example of Arabic and Ukrainian. The study is based on the hypothesis of linguistic relativity as less counter-argumentative compared to linguistic determinism. However, it is not possible to completely distinguish these two sides of the theory, so the presented evidence in a further study can also be classified as linguistic determinism.

In particular, the issues of the influence of languages on the worldview of the speaker and ways of interpreting the world around and decryption the received messages are considered. It is due to this influence that the lexical structure of most languages differs or, conversely, is similar, because certain concepts may or may not be identical.

The translation aspect, in addition to the direct translation of lexical items, concerns the translator's understanding not only of the linguistic composition of the received text in the original language, but also its equivalent adaptation into the language of translation.

The article aims to form certain lexical groups that can be problematic in translation. As a result, the paper presents a classification designed to deepen the understanding of the linguistic and cultural aspects of Arabic and Ukrainian, given the differences between the European and Eastern worldviews. The question is complicated by the instability of language, its constant evolution, along with civilizational and cultural development.

To facilitate the translation, variants of interpretation of a certain nationally colored vocabulary of Ukrainian and Arabic languages are also presented. The difference between the languages was considered in terms of territorial, religious and socio-cultural aspects, in particular concerning translations of these features. The assumption that a translator cannot fully understand a foreign language is also refuted.

Thus, language is not a purely linguistic phenomenon, as well as translation, and affects various philosophical, psychological, historical, and cultural aspects.

Key words: hypothesis of linguistic relativity, linguistic determinism, translation, the Arabic language, the Ukrainian language.

Марія ЛИХОШЕРСТОВА, orcid.org/0000-0003-4026-0539

кандидат філологічних наук, дочент кафедри східної філологіi Київського начіонального лінгвістичного університету (Київ, Україна) mariia.lykhosherstova@knlu.edu.ua

Дарина БУРЯК, orcid.org/0000-0002-5211-0688 магістранта факультету сходознавства Київського національного лінгвістичного університету (Київ, Україна) venetika99@gmail.com

\section{ГІПОТЕЗА ЛІНГВІСТИЧНОЇ ВЦДНОСНОСТІ В АРАБСЬКІЙ І УКРАЇНСЬКІЙ МОВАХ У КОНТЕКСТІ ПРОБЛЕМ ПЕРЕКЛАДУ}

У статі представлене питання неперекладності національно забарвленої лексики та культурних контекстів на прикладі арабської та украӥнської мов. Дослідження базується на гіпотезі лінгвістичної відносності, 
як менш контраргументованої, порівняно з лінгвістичним детермінізмом. Проте, стовідсотково розмежувати иі дві сторони теорії не є можливим, тому представлені докази, при подальшому дослідженні, можуть також бути зараховані до лінгвістичного детермінізму.

Розглядаються, зокрема, питання впливу мов на світогляд мовияя та способи інтерпретування навколишнього світу та дешифрування отриманих повідомлень. Саме завдяки ицьому впливу лексичний склад більшості мов різниться чи, навпаки, є схожим, оскільки певні поняття можуть бути як ідентичними, так $i$ ні.

Перекладацький аспект, окрім безпосередньо перекладу лексичних одиниць, стосується і розуміння перекладачем не тільки лінгвістичного складу отриманого тексту мовою оригіналу, але і його рівноиінною адаптацією мовою перекладу.

Метою статті є формування певних лексичних груп, щзо можуть бути проблематичними при перекладі. Як результат, у роботі представлена класифікація, покликана поглибити розуміння мовних і культурних аспектів арабської і украӥнської мов, з огляду на різницю європейського і східного світогляду. Питання ускладнюється нестатичністю мови, ї̈ постійною еволючією, нарівні з циивілізаційним і культурним розвитком.

3 метою полегшення перекладу також представлені варіанти перекладу певної національно забарвленої лексики украӥнської і арабської мов. Різниия між мовами була розглянута з точки зору територіального, релігійного і соціокультурного аспектів, зокрема стосовно перекладів зазначених особливостей. Також спростоване припущення про неможливість повного розуміння перекладачем іноземної мови.

Таким чином, мова не є суто лінгвістичним феноменом, як і переклад, і зачіпає різні філософські, психологічні, історичні і культурологічні аспекти.

Ключові слова: гіпотеза лінгвістичної відносності, лінгвістичний детермінізм, переклад, арабська мова, украӥнська мова.

Introduction. The question of the linguistic worldview in terms of the relationship between language and the perception of the native speaker of a specific language of the environment and society has been an urgent issue of the scientific community for the last few years. Consideration of language in the context of linguistic determinism or the hypothesis of linguistic relativity leads to a broader consideration of translation problems. The presented article singles out only some examples and variants of translation of lexical units in cultural, geographical, and religious contexts. In particular, the question of the possibility of a full understanding of these lexical items by the translator is considered.

The relevance is due to the need to translate nationally colored vocabulary. In particular, the question concerns understanding the culture of the language of translation to achieve the most equivalent translation.

Another aspect is the approach to the study of linguistic relativity, which is based on the classification of V. Borodytska but revealed in the comparison of Ukrainian and Arabic languages.

Analysis of research and publications. The matter of linguistic relativity was partly studied by the Ukrainian scientists, such as Kudryavtseva N., Fomina L., Azarova L., Karaban V., Kochergan M. However, all the scientists mentioned did not study the subject of linguistic relativity on its own, but only in the matter of context, within other subjects. As for the Ukrainian studies on the topic of linguistic perception, there are no studies at all, especially regarding the Arabic language.

Concerning studies of linguistic relativity by other scholars, this paper refers to the linguistic scholar
Boroditsky V., who has many papers and studies regarding the matter of linguistic relativity and linguistic perception within different languages, however, not Arabic or Ukrainian language. In addition, the question of linguistic relativity was brought up by Worf B., who mainly studied the subject within the English language.

The aim of the article is to determine and classify the main differences in the lexical structure of the Ukrainian and Arabic languages on the example of culturological features of both languages.

Main material. Any language, of course, is created by people as a tool to meet our needs (Boroditsky, 2010). Language is the first reason and a necessary condition that shapes our ideas and thinking (Sukhoverkhov, 2015: 5).

Edward Sapir believed that the world around us was largely built on the language habits of a particular group (Whorf, 1939). The hypothesis of linguistic relativity clarifies that the environment forms language. Linguistic determinism, in contrast, highlights that language causes such a difference in worldview (Alford, 1978).

B. L. Whorf notes that it is our way of naming the situation that will determine our future behavior. For example, at the gas station, we have «barrels of gasoline» next to which a person will behave carefully. At the same time, we have "empty barrels of gasoline», next to which a person will feel more free and less responsible: smoke, throw away a cigarette butt, and so on. This is despite the fact that «empty» barrels are even more dangerous than full ones because they contain a flammable vapor (Whorf, 1939).

Any language greatly influences or even completely determines a person's worldview, which he 
adopts when learning a language (Alford, 1978: 486). B. L. Whorf always described language and culture as inseparable - two sides of the same coin (Alford, 1978: 488). According to scholars, culture, science, and language develop together, constantly influencing each other (Alford, 1978: 499). Thus, our understanding of the world is inextricably reflected in language.

Indeed, languages reflect our worldview. Another example is our orientation in space. Yes, most European languages have such concepts as «left», «right», «forward», «backward». This is how we orient ourselves in space. However, some languages do not have the concepts of «left» and «right», so every time you try to explain where something is, it is necessary to focus on the sides of the world (Boroditsky, 2010: 1). Therefore, navigation by the sides of the world in these cultures is a daily necessity.

Language also affects our understanding of things. For example, in Yucatec, the word «candle» looks like «one long wax object». So, when the native English speaker and the native Yucatec speaker were presented with a plastic comb with a handle with the need to choose a similar object: a plastic comb without a handle (similarity in material) or a wooden comb with a handle (similarity in shape), English speakers chose the second option, guided by form, and native Yucatec speakers chose a plastic comb without a handle, guided by the material (Boroditsky, 2010: 919).

Another example is the different perceptions of actions, on the example of native speakers of English and Indonesian. It was depicted: the same action performed by different actors and different actions but performed by the same actor. Native English speakers have identified images with the same action more similar than those depicting different actions performed by the same actor. With Indonesian speakers, the situation is reversed (Boroditsky, 2010: 2, 5). Research shows that learning a new language changes the way you think and bilinguals think differently depending on the language they use (Boroditsky, 2010: 4).

Thus, according to numerous studies, we can conclude that language is not just a tool created for our needs, but the language we speak both reflects our way of thinking and, to some extent, shapes it (Boroditsky, 2010: 2).

Culture and language are usually seen as something separate and unconscious, rather than as a mediator between the world and the mind (Gumperz, Levinson, 1991: 622). Although the formation of thoughts is part of the grammar of the language (Kudryavtseva, 2017: 55) because it forms it. Consideration of translation, in combination with the hypothesis of linguistic relativity, can lead to the discovery of new ways to explore the possibilities of translation (Kudryavtseva, 2017: 51-52).

It is proved that the translation does not convey the full meaning of the original text and is rather a «transformation» (Kudryavtseva, 2017: 55). Recognizing the importance of influencing the thinking of a person by the language structures with no analogues means that achieving a complete translation is unlikely. Language in such cases is identified as a direct irrational reflection of the «people's spirit», which doesn't have analogs in other languages (Kudryavtseva, 2017: 51). Even so, we should refer to translation difficulties rather than untranslatability (Kudryavtseva, 2017: 63).

As we have already mentioned, speech and semantic reproduction of events are not universal. Thus, there is a question of studying Arabic and Ukrainian languages within the matter of comparing its linguistic perception of the surrounding world within the linguistic means.

For the purpose of generalization, linguistic perception of the world is divided into three groups: space, time and objects.

Space. The most common spatial relations are as follows: direction (west, east, left, next to), distance (close, far, near), topology (indicates attributes like connectivity, adjacency, and intersections between geospatial entities) (Alnairia Fatma Ali et al., 2012: 172). Arabic and Ukrainian languages have all three mentioned types of spatial relations (Alnairia Fatma Ali et al., 2012: 178).

Direction relations can intersect with the world perception, in the matter of time understanding. For example, in such phrases as 《الابتداء / / /at the begin-

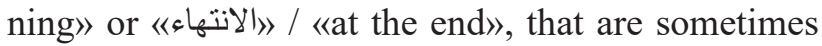
expressed by such prepositions as «نم)/ «from» and 《إلى / 《towards» (Marogy, 2012: 59).

«Від початку до кінця, (...), місія на Марс займає три роки» (Veyr, 2015: 10).

$$
3 \text { سنوات « (اتستغرق مهمة المريخ من بدايتها إلى نهايتها (...) حوالي }
$$

«Start to finish, including supply missions, a Mars mission takes about 3 years» (Weir, 2015: 3 ).

Time. Sibawayh distinguishes between three times in the Arabic language, as follows: events, that have already happened; events, that are going to happen, however haven't started yet; events, that are already in the progress (Marogy, 2012: 129). Thus, the Arabic language is quite similar to Ukrainian as to its time perception.

«ерш ніж замучитись, я встиг занести один кубометр» (Veyr, 2015: 31) 


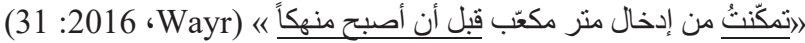

«I got a cubic meter in before getting exhausted» (Weir, 2015: 21).

«Але я не можу чекати так довго. Вся картопля 3 цього врожаю потрібна мені, щоб засадити решту поля» (Veyr, 2015: 32).

》الكن لا بمكني الانتظار كل تلك المدة. سأحتاج إلى تقطيع كل

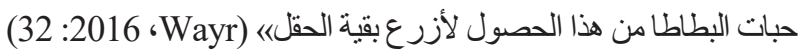

«But I can't wait that long. I'll need to cut up all the potatoes from this crop to seed the rest of the field» (Weir, 2015: 21).

These examples demonstrate the use of verbs for denoting certain event (it coincides in two cases and doesn 't in one), as well as the use of certain particles for accentuating the exact time of the event: «перш ніж», «так довго». Thus, in most cases the way of expressing of the time means by the language in Arabic and Ukrainian languages coincides.

By these examples, we also can see the difference, when in the Ukrainian language we have the immediate need and the Present Tense by «мені потрібна», however in Arabic translation we have no Present, but Future Tense for the same action سأحتاج). This happens because of the grammatical means of the languages, as Arabic Present Tense only marks an action, which happens at the same time as the speaker speaks, so it can partly mark the Future action, but cannot mark the prediction of the Future (Shukri, 1991: 120), which, as we see by the examples, is possible in the Ukrainian language.

Objects. The Ukrainian language has three grammatical genders: feminine, masculine and neutral (Fomina, 2013: 14). The Arabic language has, however, two grammatical genders: feminine and masculine. Every verb, noun, adjective, personal, demonstrative, or relative pronoun, has to be concorded in gender, if related to a noun in a syntactical sentence structure (Alkohlani, 2016: 19), especially when in the Ukrainian language the use of a personal pronoun is more common:

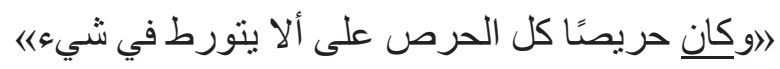

\section{( $7: 1850$ Stīfinsūn)}

«Biн був обережний і ні у що не вплутувався» (Stivenson, 2010: 7)

This example demonstrates the absence of the personal pronoun in the Arabic translation, which should be used for the Ukrainian language. Even so, the gen- der of the character remains obvious. The definition of gender usually depends on the semantic criterion, that is, the natural gender, as well as on the morphological form. In Arabic language, the masculine gender is not usually indicated, comparing to the feminine gender. Most feminine nouns have a typical ending in both the singular and plural. Plural nouns for inanimate objects also have feminine plural ending (Alkohlani, 2016:20).

For the purpose of comparison, lexical representation of the surrounding world in Ukrainian and Arabic languages was divided into three groups: territorial (geographical), religious and socio-cultural.

Territorial group - contains vocabulary, related to geographical features. In the Arabic language, the word «camel» can be an example, due to its wide range of

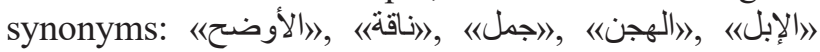

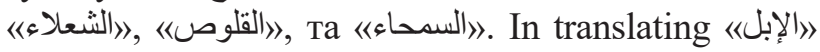
and الهجن the translator will face no difficulty because they are used interchangeably in Arabic to refer to both genders and camels of all sizes and kinds. As for the 《جل and 《ناقة) are translated as «верблюд» / «male camel» and «верблюдиця» / «female camel» respectively. In addition to gender distinction, the rest of the words can be translated by paraphrasing the camels' distinctive features. For instance, 《الأوضح will be translated as «білий верблюд (чоловічого роду)» / 《male white camel», whereas 《القلوصا》can be translated as «дворічна верблюдиця, на якій можна їздити верхи» / «two-year young female camel that can be ridden». 《الثعلاء that is distinguished by its redness and fastness will be rendered as «рудий верблюд для перегонів» / «red race camel», and 《السمحاء), which is known of its color mixture: red and black, will be translated as «чорно-рудий верблюд» / «black and red camel» (Eshraq Obeidat, 2017: 42).

The territorial group also includes vocabulary about climatic features. These are, for instance, winter landscapes in the Ukrainian language as «сніжинка», «крига», «мороз», «відлига» еtс., as well as verbs, related to winter. Here we should consider the Arabic translation of the mentioned vocabulary.

«А надворі мела метелиця» (Andersen, 2013:4).

$$
\text { 》حيث ينجرف الجليديا (Andirsin) '، 2014: 106). }
$$

«Сніг повалив раптом ще дужче» (Andersen, 2013, c. 6).

\section{》اوبدأ الجليد يتساقط بكثافة《) (Andirsin'، 2014: 110).}

«А сніг падав, i сани мчали, поринаючи в заметах, стрибаючи через тини та рівчаки» (Andersen, 2013: 7). 


\section{"وتكست أكوام الجليد، واندفعت فوقها مركبة الانزلاق، \\ وبين حين وآخر، صارت تقفز كها لو كانت تطير فوق الحفر

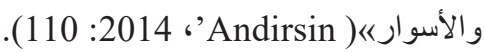

«Снігові пластівці все росли, росли i, нарешті, зробилися як великі білі кури» (Andersen, 2013: 6).

$$
\text { (صارت أكو ام الجليد أكبر و أكبر ، وأخيراً ظهرت كأنها دجاجات }
$$

كيبرة؛ (Andirsin) ، 2014: 111).

The first example demonstrates the absence of the concept «метелиця» in the Arabic language, which is replaced by the word «snow». The next example also shows an absence of the accentuating the heavy snowfall, which in Ukrainian is accentuated by the verb «повалив», but in Arabic only the verb for «falling» is used. The third example demonstrates the translation into the Arabic language of the concept «сани», which is absent in the receiving culture and, as the result, is translated as «sliding vehicle». The next example shows referring to the «снігові пластівці» as «snow piles», as well as omitting of the accentuating on the colour "white» in the comparison of the snow with «big white chickens». Thus, we can see multiple omissions of the accentuating on the heavy snow, etc., which can be caused by the absence of such notions and association in the receiving culture. Thus, there is no literal need to accentuate the notions mentioned.

The next group includes religious vocabulary. Understanding certain emotional connotations of some synonyms in the Quran can be problematic for

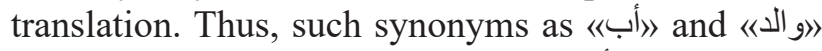
are used in different connotations: 《أب) is a general utterance that refers to the person who provides another person with food and shelter and is concerned with the education of that person both physically and mentally. Moreover, he also provides guidance and counseling. In contrast, the term 《و الدا is used only to refer to a biological parent who is the immediate father or mother and is always associated with emotions and compassion unlike the first term «أب which is associated with logic and reason (Sana Kamel AlOmari, 2014: 2625).

The last group mentioned is socio-cultural, which includes vocabulary about traditional heritage. The family pattern is mainly related to the opposition husband-wife. In the Arabic language «husband» / 《زوج) - is anyone, who has a pair, and «wife» /
《زاجوجة - is man's wife (Shaykhullin, 2012: 21). In the Ukrainian language, «husband» / «чоловік»- is a married man, concerning his wife (Bilodid, 1980: 349), and «дружина» / «wife» - is a married woman, concerning her husband (Bilodid, 1971: 424). Considering these definitions, we see the traditional marriage differences, as it has been a free will to marry in the Ukrainian culture and husband and wife have been seen as equals (Yovenko, 2010: 6). Whereas, in the traditional Arabic culture, marriage has a masculine orientation, where wife's life hasn't been self-determining but rather oriented to her husband's needs and life (Shaykhullin, 2012: 22).

Another difference is related to the term «orphans». In Ukrainian proverbs, orphans are seen as an example of tough fate: «Бог сиріт любить, та щастя-долі не дає», «Сироті хоч з моста та в воду» (Nomys, 1993). In Arabic traditional culture the role of orphans is less notable, there is only a mention that stepparents won't replace birth parents. Moreover, there are no terms as «stepparents», but «mother's husband» and «father's wife» (Shaykhullin, 2012: 31), which indicates that such term is not popular.

Another example: extensive system in the Ukrainian language of names of relatives «through marriage»: свекор, дівер, тесть, зять, шурин, кум, кума, сват, сваха; which does not exist in the Arabic language. Such difference may be explained as Arabic culture focus less on the distant kinship ties (Shaykhullin, 2012: 35). As for the close ties, there is an opposite situation, where the Ukrainian language only has such terms as «тітка» and «дядько», when the Arabic language differentiates between «father's

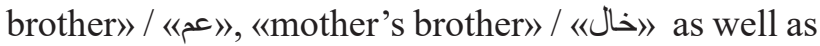
《father's sister» / 《عمة /خالة) / and 《mother's sister》 (Shaykhullin, 2012: 35).

Conclusions. Studies have shown, that different native speakers focus on different aspects of a certain event or object for compliance with the structural rules of the language. This particularly applies to the reflection of time, space, objects, etc. As for the translation, this raises the question of the translator's reflection of language and cultural aspects of the original language into the translation, as there is a high chance of the semantic misinterpretation of the text.

For further studies, the observational methodology is needed, via associative opinion poll of Arabic and Ukrainian native speakers for more accurate interpretation examination of certain concepts.

\section{BIBLIOGRAPHY}

1. Alford Danny K. H. The Demise of the Whorf Hypothesis (A Major Revision in the History of Linguistics). Proceedings of the 4th Annual Meeting of the Berkeley Linguistics. Berkeley, California, 1978. pp. 485-499. 
2. Alkohlani Fatima A. The problematic issue of grammatical gender in Arabic as a foreign language. Journal of Language and Cultural Education. 2016. pp. 17-28.

3. Alnairia Fatma Ali, Nazlia Omar, Albared Mohammed. Extraction of Spatial Relation in Arabic Text Using Rule-Based Approach. International Journal of Advancements in Computing Technology. 2012. pp. 172-178.

4. Boroditsky L., Ham W., Ramskar M. What is universal in event perception? Comparing English \& Indonesian speakers. Proceedings of the Twenty-Fourth Annual Conference of the Cognitive Science Society. 2002. pp. 136-141.

5. Boroditsky L. Linguistic Relativity. Encyclopedia of Cognitive Science. 2006. pp. 917-921.

6. Boroditsky L. Lost in translation. The Wall Street Journal. 2010. URL: https://www.wsj.com/articles/SB10001424052 748703467304575383131592767868 (accessed: 15.04.2021).

7. Eshraq Obeidat Abdel-Rahman Husni Abu-Melhim. Lexical Relations between English and Arabic: The Role of the Translator. International Journal of English Language and Linguistics Research. European Centre for Research Training and Development UK, 2017. pp. 40-49.

8. Gumperz John J., Levinson Stephen C. Rethinking Linguistic Relativity. Current Anthropology. 1991. pp. 613-623.

9. Marogy A. E. The Foundations of Arabic Linguistics. Sĩbawayhi and Early Arabic Grammatical Theory. Boston : Brill, 2012. $236 \mathrm{p}$.

10. Sana Kamel Al-Omari Abdel-Rahman Husni Abu-Melhim. Synonymy in English and Arabic with Reference to the Holy Qur'an: A Contrastive Study. Theory and Practice in Language Studies. 2014. pp. 2619-2626.

11. Shukri B. Abed Aristotelian Logic and the Arabic Language in Alfarabi. New York : State University of New York Press, $1991.240 \mathrm{p}$.

12. Weir A. The Martian. London: Penguin Random House UK, 2015. 369 p.

13. Whorf B. L. The relation of habitual thought and behavior to language. Language, culture, and personality, essays in memory of Edward Sapir. 1939. pp. 75-93.

14. Андерсен Х. К. Снігова королева. Київ : Країна Мрій, 2013. 368 с.

15. Білодід І. К. Словник української мови : Т. 2 . Київ : Наукова думка, 1971.550 с.

16. Білодід І. К. Словник української мови : Т. 11. Київ : Наукова думка, 1980. 699 с.

17. Вейр Е. Марсіянин. Київ : Країна Мрій, 2015. 416 с.

18. Йовенко Л. І., Терешко І. Г. Традиційне родинне виховання українців: Навчальний посібник для студентів вищих. Умань : РВЦ «Софія», 2010. 239 с.

19. Кудрявцева Н. Лінгвістична відносність і проблеми перекладу філософської термінології: лінгвокогнітивний підхід (монографія). Київ : Видавничий дім Дмитра Бураго, 2017. 468 с.

20. Номис М. Українські приказки, прислів'я і таке інше. Київ : Либідь, 1993. 764 с.

21. Стівенсон Р. Л. Химерна історія доктора Джекіла і містера Гайда. Полтава : Країна Мрій, 2010. 86 с.

22. Суховерхов А. В. Лингвистический детерминизм, кумулятивная эволюция и рост научного знания. Политематический сетевой электронный научный журнал Кубанского государственного аграрного университета. Краснодар : КубГАУ, 2014. № 07 (101). С. 1-21.

23. Фоміна Л. Ф. Порівняльна граматика української та російської мов. Морфологія: конспект лекцій. Одеса : Одеський національний університет, 2013. 85 с.

24. Шайхуллин Т. А. Русские и арабские паремии с компонентом-наименованием родственных отношений: концептуально-семантический и этнокультурный аспекты : дис. ... докт. филол. наук: 10.02.01. Казань : Институт филологии и искусств Казанского (Приволжского) университета, 2012. 380 с.

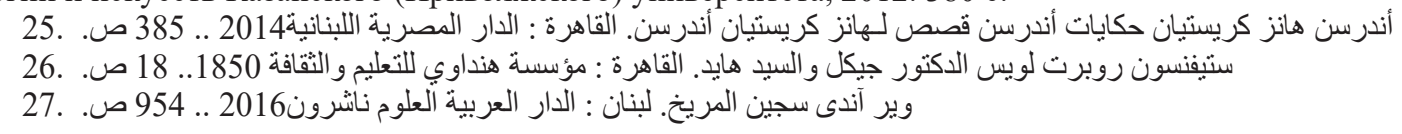

\section{REFERENCES}

1. Alford Danny K. H. The Demise of the Whorf Hypothesis (A Major Revision in the History of Linguistics). Proceedings of the 4th Annual Meeting of the Berkeley Linguistics. Berkeley, California, 1978. pp. 485-499.

2. Alkohlani Fatima A. The problematic issue of grammatical gender in Arabic as a foreign language. Journal of Language and Cultural Education. 2016. pp. 17-28.

3. Alnairia Fatma Ali, Nazlia Omar, Albared Mohammed. Extraction of Spatial Relation in Arabic Text Using Rule-Based Approach. International Journal of Advancements in Computing Technology. 2012. pp. 172-178.

4. Boroditsky L., Ham W., Ramskar M. What is universal in event perception? Comparing English \& Indonesian speakers. Proceedings of the Twenty-Fourth Annual Conference of the Cognitive Science Society. 2002. pp. 136-141.

5. Boroditsky L. Linguistic Relativity. Encyclopedia of Cognitive Science. 2006. pp. 917-921.

6. Boroditsky L. Lost in translation. The Wall Street Journal. 2010. URL: https://www.wsj.com/articles/SB10001424052 748703467304575383131592767868 (accessed: 15.04.2021).

7. Eshraq Obeidat Abdel-Rahman Husni Abu-Melhim. Lexical Relations between English and Arabic: The Role of the Translator. International Journal of English Language and Linguistics Research. European Centre for Research Training and Development UK, 2017. pp. 40-49.

8. Gumperz John J., Levinson Stephen C. Rethinking Linguistic Relativity. Current Anthropology. 1991. pp. 613-623.

9. Marogy A. E. The Foundations of Arabic Linguistics. Sỉbawayhi and Early Arabic Grammatical Theory. Boston : Brill, 2012. $236 \mathrm{p}$. 
10. Sana Kamel Al-Omari Abdel-Rahman Husni Abu-Melhim. Synonymy in English and Arabic with Reference to the Holy Qur'an: A Contrastive Study. Theory and Practice in Language Studies. 2014. pp. 2619-2626.

11. Shukri B. Abed Aristotelian Logic and the Arabic Language in Alfarabi. New York : State University of New York Press, $1991.240 \mathrm{p}$.

12. Weir A. The Martian. London: Penguin Random House UK, 2015. 369 p.

13. Worf B. The relation of habitual thought and behavior to language. Language, culture, and personality, essays in memory of Edward Sapir. 1939. pp. 75-93.

14. Andersen Kh. K. Snihova koroleva [The Snow Queen]. Kyiv : Krayina Mriy, 2013. 368 p. [in Ukrainian].

15. Bilodid I. K. Slovnyk ukrayins'koyi movy [Dictionary of the Ukrainian language] : T. 2 . Kyiv : Naukova dumka, 1971. 550 p. [in Ukrainian].

16. Bilodid I. K. Slovnyk ukrayins'koyi movy [Dictionary of the Ukrainian language] : T. 11 Kyiv : Naukova dumka, 1980. 699 p. [in Ukrainian].

17. Veyr E. Marsiyanyn. Kyiv : Krayina Mriy, 2015. 416 p. [in Ukrainian].

18. Yovenko L. I., Tereshko I. H. Tradytsiyne rodynne vykhovannya ukrayintsiv: Navchal'nyy posibnyk dlya studentiv vyshchykh [Traditional family upbringing of Ukrainians: A textbook for university students]. Uman’ : RVTS «Sofiya», 2010. 239 p. [in Ukrainian].

19. Kudryavtseva N. Linhvistychna vidnosnist' i problemy perekladu filosofs'koyi terminolohiyi: linhvokohnityvnyy pidkhid (monohrafiya) [Linguistic relativity and problems of translation of philosophical terminology: linguocognitive approach (monograph)]. Kyiv : Vydavnychyy dim Dmytra Buraho, 2017. 468 p. [in Ukrainian].

20. Nomys M. Ukrayins'ki prykazky, prysliv'ya i take inshe [Ukrainian proverbs, sayings and so on]. Kyiv : Lybid', 1993. 764 p. [in Ukrainian].

21. Stivenson R. L. Khymerna istoriya doktora Dzhekila i mistera Hayda [Strange Case of Dr. Jekyll and Mr. Hyde]. Poltava : Krayina Mriy, 2010. 86 p. [in Ukrainian].

22. Sukhoverkhov A. V. Lingvisticheskiy determinizm, kumulyativnaya evolyutsiya i rost nauchnogo znaniya [Linguistic determinism, cumulative evolution and the growth of scientific knowledge]. Politematicheskiy setevoy elektronnyy nauchnyy zhurnal Kubanskogo gosudarstvennogo agrarnogo universiteta. Krasnodar : Kuban State Agrarian University, 2014. № 07 (101). pp. 1-21 [in Russian].

23. Fomina L. F. Porivnyal'na hramatyka ukrayins'koyi ta rosiys'koyi mov. Morfolohiya: konspekt lektsiy [Comparative grammar of Ukrainian and Russian languages. Morphology: lecture notes]. Odesa : Odessa National University, 2013. 85 p. [in Ukrainian].

24. Shaykhullin T. A. Russkiye i arabskiye paremii s komponentom-naimenovaniyem rodstvennykh otnosheniy: kontseptual'no-semanticheskiy i etnokul'turnyy aspekty [Russian and Arab paremias with the component-name of kinship relations: conceptual-semantic and ethnocultural aspects]: dis. ... dokt. filol. nauk: 10.02.01. Kazan : Institute of Philology and Arts of Kazan (Volga Region) University, 2012.380 p. [in Russian].

25. 'Andirsin Hānz Krīstīyān. Hikāyāt 'Andirsin qysas li-Hānz Krīstīyān 'Andirsin. Al-Qāhira : al-dār al-miṣiyya al-lubnāniya. 2014. 583 p. [In Arabic].

26. Stīfinsūn Rūbirt Lūys. Al-duktūr Jīkil wal-sayid Hāyd. Al-Qāhira : mu’assasa handāwī lil-ta'alīm wal-țaqāfa. 1850. 81 p. [In Arabic].

27. Wayr Āndī. Sajīn al-marīhn. Lubnān : al-dār al-‘arabiya al-‘ulūm nāšrūn. 2016. 459 p. [In Arabic]. 